\title{
HIV stigma and associated factors among antiretroviral treatment clients in Jimma town, Southwest Ethiopia
}

This article was published in the following Dove Press journal:

HIVIAIDS - Research and Palliative Care

23 November 2016

Number of times this article has been viewed

\section{Neno Nikus Fido \\ Mamusha Aman \\ Zewdie Brihnu}

Department of Health Education and Behavioral Sciences, Jimma University, Jimma, Ethiopia
Correspondence: Neno Nikus Fido Department of Health Education and Behavioral Sciences, Jimma University College of Public Health and Medical Sciences, PO Box No. 378, Jimma, Ethiopia

Tel +25I 9275925 I 4

Email nenoniqus@gmail.com

Background: HIV stigma has an important role in the spread of the AIDS epidemic. It profoundly affects the lives of individuals living with HIV/AIDS. Fear of being identified as having HIV may discourage a person from getting tested, accessing medical services, and obtaining medications. Thus, this study was aimed at assessing HIV-related stigma and associated factors among antiretroviral treatment (ART) clients in Jimma town, Oromia region, Southwest Ethiopia. Methods: A facility-based cross-sectional study was conducted from March 11 to April 26, 2015, in ART clinics in Jimma town. Consecutively identified sample was obtained from ART clients who voluntarily participated in the survey after signing written consent. A structured interviewer-administered questionnaire was used to collect the data. Multiple linear regressions were conducted to assess the factors associated with various stigma domains.

Results: Out of 349 clients requested, 318 (91.1\%) respondents voluntarily participated in the study; among them, 204 (64.2\%) respondents were females and the mean age of the respondents was 32.9 years. The mean score (and possible range) of experienced HIV stigma was 41.5 \pm 12.6 (20.0-86.7), internalized stigma was 50.5 \pm 16.4 (20-96.5), and perceived stigma was $56.2 \pm 19.2(20-100)$.

Conclusion: The study revealed that duration of ART use and provider-initiated and forced HIV testing were significantly associated with the three HIV stigma domains. Despite the lower experienced HIV stigma, there were higher internalized and perceived stigmas. Therefore, HIV counseling services should be strengthened for new ART beginners, including pretest counseling. Keywords: HIV/AIDS, Jimma, stigma, ART clients, PLWHA

\section{Introduction}

In 2013, it was estimated that about 35 million people worldwide are living with HIV. Sub-Saharan Africa remains the region most affected by the pandemic, holding more than two-thirds of all infected people. ${ }^{1}$ Ethiopia has not escaped the burden with an estimated adult prevalence of $1.5 \%,{ }^{2}$ large numbers of people living with HIV, and millions of children orphaned due to AIDS. ${ }^{3}$ Ethiopia has nine regional states and two city administrations. In 2010, the single point estimate of the country indicated that adult HIV prevalence in Oromia regional state was 1.6, which was slightly higher than the national single point estimate and the total PLWHA (people living with HIV/AIDS) in the region was estimated at 287,301 persons. $^{4}$

Stigma has been associated with a number of diseases such as leprosy, urinary incontinence, and mental illness; nevertheless, most of the existing studies and commentaries have noted that stigma remains a major fact of life for PLWHA in sub-Saharan Africa 5 and referred it as "central to the global AIDS challenge as the disease itself". ${ }^{6}$ 
HIV/AIDS-related stigma is a complex concept that refers to prejudice, discounting, discrediting, and discrimination directed at persons perceived to have AIDS or HIV. As a result, the global commission on HIV/AIDS urged that member countries should take immediate steps to cancel punitive laws, prohibit stigma and discrimination, ${ }^{7}$ and work toward zero stigma and discrimination. A recent systematic review found that over the last decade, evidence-based effective programming to reduce stigmatizing and discriminatory attitudes has expanded substantially. ${ }^{8}$ However, almost no country has prioritized activities to reduce or eliminate them in their national AIDS plans or program. ${ }^{9}$ HIV stigma continues to have an extremely important role in the AIDS epidemic, not only because of its effects on HIV-infected individuals but also because of the ways in which it might be contributing to the spread of the epidemic. ${ }^{10}$ People who experience stigma report a range of negative effects, including loss of income or job, isolation from communities, and inability to participate as a productive member of society. ${ }^{11}$ Stigma also hinders adherence to antiretroviral treatment (ART), accelerates disease progression, ${ }^{12,13}$ and develops low self-esteem, accompanied by feelings of anger and revenge, and emotional stress. ${ }^{14}$ However, counseling of PLWHA and education of health workers and the community would lead to reductions in this negative self-perception and verbal abuse and in turn improve the quality of life for PLWHA. ${ }^{15}$

Some studies have showed that aspects of stigmas have been reported as factors constituting a serious obstacle for HIV counseling and testing (VCT) service utilization and HIV prevention, ${ }^{16}$ and PLWHA tend to experience self- and anticipated stigmas due to their weak appearance caused by HIV-related complication, particularly during life before receiving ART. ${ }^{17}$ The different aspects are all interrelated and may have an impact on the self-efficacy of the affected person, his or her participation in the community, personal well-being, and self-esteem. ${ }^{18}$ The PLWHA experience unemployment rates three times higher than national unemployment rates in different countries, and the reason for unemployment includes stigma. ${ }^{19}$ The PLWHA in Ethiopia experience stigmatization through gossip, verbal insult, isolation, and rejection according to a stigma index survey conducted by networks of positive people (NEP+) ${ }^{20}$ Despite the fact that large numbers of PLWHA are found in Jimma town, the situation of HIV stigma has not been well addressed in various literatures. Therefore, the major aim of this study was to assess the level of HIV stigma among ART clients and different factors affecting the stigma.

\section{Methods}

\section{Study design and setting}

A facility-based cross-sectional survey was conducted in health facilities providing ART service for PLWHA in Jimma town. Jimma town is located $355 \mathrm{~km}$ away to the southwest of Addis Ababa in Oromia regional state. There are four health centers, one district hospital, and one specialized referral hospital in the town. However, only three health facilities, Jimma University Specialized Hospital, Shenen Gibe District Hospital, and Jimma town health center, were providing ART services. The study was conducted from March 11 to April 26, 2015, in these ART clinics.

\section{Population and sampling}

The sample size was calculated using single population proportion considering the prevalence $(\mathrm{p}=0.86)$, margin of error $(\mathrm{d}=0.04)$, and level of significance $(\alpha=0.05)$ at $95 \%$ confidence interval (CI). This gave a sample size of 318 ART clients. All ART clients attending the clinics during the study period were source population. Only ART clients older than 18 years of age were eligible for the study. The ART clients were recruited consecutively by ART nurses during their visit to the clinics in the selected health facilities.

\section{Measure tools}

A structured questionnaire was adapted from HIV stigma index validation survey conducted in six Iranian cities. ${ }^{21}$ The questionnaire was translated into local languages (i.e. Amharic and Afan Oromo) and translated back to English to check for consistency. It comprised items used to assess sociodemographic information (9 items), HIV testing and diagnosis information (5 items), social support information ( 7 items), and the stigma scale (45 items). The stigma scale was further classified as experienced stigma (18 items), perceived stigma (10 items), and internalized stigma (17 items). Each of the scales was rated on a five-point scale: $1=$ strongly disagree, 2 =disagree, 3 =undecided, 4=agree, and $5=$ strongly agree. The questionnaire was pretested in similar facility found in the nearest town before the actual data collection.

\section{Operational terms}

\section{Experienced stigma}

It is an act of discrimination PLWHA faced, including denial of health care, loss of education or employment, or isolation from family members. 


\section{Internalized stigma}

The negative self-image of PLWHA which may have resulted from perceived and/or experienced stigma like ashamed and blaming self because of being HIV-positive.

\section{Perceived stigma}

How PLWHA feel that they are being negatively treated by partners, family, friends, health care providers, and members of their community because of their HIV status.

\section{Data collection procedure}

A two-day training was provided to the ART nurses on data collection tools, after which they started collecting the data in their respective clinics. The principal investigator supervised the data collection process on a daily basis.

\section{Data analysis}

The data were cleaned, coded, and entered into EPI data version 3.1 templates and exported to SPSS version 20.0 for further statistical analysis. The sample adequacy was observed as Kaiser-Mayer-Olkin index $=0.90$ and $\mathrm{p}=0.000$. The three stigma domains were checked for internal reliability, and Cronbach's alphas were found to be $0.87,0.89$, and 0.87 for internalized, perceived, and experienced HIV stigma, respectively. The scores of the stigma items were initially computed and summed up and calculated in percentages to ease comparison among the stigma domains. The percentage scores were used as a continuous variable after checking for normality, collinearity, and linearity to conduct linear regression. Descriptive statistical analysis was done, and simple linear regression was used to check the association between independent variables and each domain of stigma. Variables with a $p$-value $\leq 0.25$ in simple regression analysis were entered into multiple linear regression models.

\section{Ethical considerations}

Ethical approval was obtained from the Institutional Review Board of the College of Public Health and Medical Sciences of Jimma University. All study participants were informed about the purpose of the study, and written informed consent was obtained from all participants.

\section{Results}

\section{Background characteristics of the respondents}

Out of 349 ART clients requested to participate in the study, $318(91.1 \%)$ responded to the study tools. Two hundred and four (64.2\%) participants were females. One hundred and forty-four (45.3\%) respondents were at the age of 30-39 years, and the mean age of the respondents was $32.9 \pm 8.1$ years. One hundred and thirty-six $(42.8 \%)$ respondents were Orthodox Christians in religion. Concerning ethnicity, 120 (37.7\%) and 107 (33.6\%) of them were from Oromo and Amhara ethnic group, respectively. More than half of the respondents, 164 (51.6\%), were married. The majority (79.6\%) respondents had at least an elementary school education (Table 1).

\section{HIV testing and diagnosis}

Almost more than half of the respondents, 162 (50.9\%), were tested for HIV as they were suspected by health workers. The other reasons included self-motivation during VCT campaign, HIV-positive status of spouse, illness, or death of spouse. Of all respondents, $7.6 \%$ reported that they were tested through coercion or without their knowledge. The majority (81.1\%) of the respondents had been using ART for more than 1 year, while $60(18.9 \%)$ of the respondents had been using ART for 1 year and less. Regarding the status of disclosure, 71 (22.3\%) respondents blamed other people for disclosing their HIV status without their knowledge where health care providers were the major breach of confidentiality (Table 2).

\section{Social support experience}

Two hundred and sixty-eight (84.3\%) respondents were living with at least one family member. One hundred and eightynine (59.4\%) respondents had someone/partner in the house who encouraged them to take the ART and other prescribed drugs timely. Seventy (22.0\%) respondents were members of legally established association and NEP+. More than half of the respondents, 174 (54.7\%), had different social supports at least once in the past 3 months, and almost all, 312 (98.1), of the respondents believed that HIV counselors provided information that helped them to cope up with the effects of HIV/AIDS (Table 3).

\section{Experienced HIV stigma}

The experienced HIV stigma score was found to be $41.5 \pm 12.6$ with a possible range between 20.0 and 86.7. The approval response of the respondents to each experienced HIV stigma items indicated that more than half, $186(58.5 \%)$, of the respondents indicated that they were aware of being gossiped about, while 127 (39.9\%) respondents reported verbal insult or harassment by their subordinate due to their HIV status (Table 4). 
Table I Sociodemographic characteristics of the respondents $(N=3 \mid 8)$ among ART clients in jimma town

\begin{tabular}{|c|c|c|c|c|c|}
\hline \multicolumn{2}{|c|}{ Characteristic } & \multirow{2}{*}{$\frac{\text { n (\%) }}{1 \mid 4(35.8)}$} & \multicolumn{2}{|l|}{ Characteristic } & \multirow{2}{*}{$\frac{\text { n (\%) }}{120(37.7}$} \\
\hline$\overline{S e x}$ & Male & & Ethnicity & Oromo & \\
\hline & Female & $204(64.2)$ & & Amhara & $107(33.6)$ \\
\hline \multirow[t]{5}{*}{ Age (years) } & $\leq 24$ & $39(12.3)$ & & Kaffa & $31(9.7)$ \\
\hline & $25-29$ & $74(23.3)$ & & Gurage & $19(6.0)$ \\
\hline & $30-39$ & $144(45.3)$ & & Tigre & $16(5.0)$ \\
\hline & $40-49$ & $48(15.1)$ & & Other $^{\mathrm{a}}$ & $25(7.9)$ \\
\hline & $\leq 50$ & $13(4.1)$ & Education & No education & $65(20.4)$ \\
\hline \multirow[t]{4}{*}{ Marital status } & Single & $48(15.1)$ & & Grade I-8 & $135(42.5)$ \\
\hline & Married & $164(5 \mid .6)$ & & Grade 9-12 & $72(22.6)$ \\
\hline & Divorced & $51(16.0)$ & & College education & $30(9.4)$ \\
\hline & Widowed & $55(17.3)$ & & Higher education & $16(5.0)$ \\
\hline \multirow[t]{7}{*}{ Occupation } & Government employee & $60(18.9)$ & Religion & Orthodox Christian & $136(42.8)$ \\
\hline & Private fulltime employee & $36(11.3)$ & & Muslim & $105(33.0)$ \\
\hline & Temporary/part time employee & $42(13.2)$ & & Other & $77(24.2)$ \\
\hline & Daily laborer & $59(18.6)$ & Average monthly income & $\leq 750$ & $169(53.1)$ \\
\hline & Merchant & $56(17.6)$ & (Birr) & $\geq 75 \mathrm{I}$ & 149 (46.9) \\
\hline & Student & $36(11.3)$ & & & \\
\hline & Other ${ }^{c}$ & $29(9.1)$ & & & \\
\hline
\end{tabular}

Notes: alncluded Silte, Dawaro, and Yem. Included traditional beliefs and nonbelievers. Included commercial sex workers, religious workers, and house servants. Abbreviation: ART, antiretroviral treatment.

Table 2 The experiences of HIV testing and diagnosis of the respondents $(\mathrm{N}=3 / 8)$ among ART clients in Jimma town

\begin{tabular}{|c|c|c|}
\hline Characteristics & Category & n (\%) \\
\hline \multirow[t]{4}{*}{ Years of ART use } & $2-3$ & $103(32.4)$ \\
\hline & 6 and above & $93(29.2)$ \\
\hline & $4-5$ & $62(19.5)$ \\
\hline & I and less & $60(18.9)$ \\
\hline \multirow[t]{9}{*}{$\begin{array}{l}\text { Reason for HIV testing } \\
\text { for the first time }\end{array}$} & $\begin{array}{l}\text { Referral due to suspected HIV } \\
(\mathrm{eg}, \mathrm{TB})\end{array}$ & $162(50.9)$ \\
\hline & $\begin{array}{l}\text { Just wanted to know during } \\
\text { VCT campaign }\end{array}$ & $73(23.0)$ \\
\hline & $\begin{array}{l}\text { Spouse/partner/family member } \\
\text { HIV+ }\end{array}$ & $25(7.9)$ \\
\hline & $\begin{array}{l}\text { Illness of spouse/partner/family } \\
\text { member }\end{array}$ & $17(5.3)$ \\
\hline & $\begin{array}{l}\text { Death of spouse/partner/family } \\
\text { member }\end{array}$ & $15(4.7)$ \\
\hline & Due to pregnancy ANC service & $14(4.4)$ \\
\hline & Referral by clinics for STIs & $6(1.9)$ \\
\hline & $\begin{array}{l}\text { Preparation for marriage or } \\
\text { sexual relation }\end{array}$ & $3(0.9)$ \\
\hline & Due to other reasons & $3(0.9)$ \\
\hline \multirow{3}{*}{$\begin{array}{l}\text { Who was decided to be } \\
\text { tested for HIV for the } \\
\text { first time? }\end{array}$} & It was my voluntary action & $190(59.7)$ \\
\hline & $\begin{array}{l}\text { I took the decision, but it was } \\
\text { under pressure }\end{array}$ & $104(32.7)$ \\
\hline & $\begin{array}{l}\text { I was made to take an HIV test } \\
\text { (coercion) }\end{array}$ & $24(7.5)$ \\
\hline Has your HIV-positive & No & $247(77.7)$ \\
\hline \multicolumn{3}{|l|}{ without your consent? } \\
\hline Whom do you blame & Employer/colleague/friend & $29(40.8)$ \\
\hline for disclosing your HIV & Family members/caregiver & $22(31.0)$ \\
\hline status without consent? & Health service providers & II (I5.5) \\
\hline \multirow[t]{2}{*}{$(\mathrm{N}=7 \mathrm{I})$} & Spouse/sexual partner & $5(7.0)$ \\
\hline & Others & $4(5.6)$ \\
\hline
\end{tabular}

Abbreviations: ART, antiretroviral treatment; TB, tuberculosis; VCT, HIV counseling and testing; ANC, antenatal care; STIs, sexually transmitted infections.

\section{Internalized HIV stigma}

Internalized HIV stigma score was in the range of 20-96.5 with a mean score of $50.5 \pm 16.4$. The majority of respondents (71.1\%) felt that their self-esteem lowered as 221 (69.5\%) felt ashamed and 199 (62.9\%) felt fear of being gossiped about due to HIV-positive status. Moreover, a significant number of respondents $(8.8 \%)$ had decided to stop participating in various social gatherings. Of all respondents, $7.9 \%$ had decided to stop education/training in the past 12 months due to fear of stigma (Table 5).

\section{Perceived HIV stigma}

The mean score of perceived HIV stigma was $56.2 \pm 19.2$ with range between 20 and 100. More than half of the respondents $(61.1 \%)$ had developed fear of discrimination, while $171(53.8 \%)$ respondents were worried about involuntary disclosure (Table 6).

\section{Factors associated with experienced HIV stigma}

The final model of multiple linear regression identified that being a female increased the score of experienced HIV stigma on average by 6.7 ( $\beta=6.73 ; p=0.00 ; 95 \%$ CI $3.2,10.3$ ), and being a widowed woman increased the score by 12.3 as compared to divorced woman ( $\beta=12.3 ; p=0.00 ; 95 \%$ CI 7.2, 17.4). Education status was also significantly associated with experienced HIV stigma. The stigma score was also higher among uneducated respondents compared to those who attended at least secondary (Grade 9-12) education $(\beta=14.5$; 
Table 3 The experience of social support among respondents $(\mathrm{N}=318)$ among ART clients in Jimma town

\begin{tabular}{|c|c|c|c|c|c|}
\hline \multicolumn{2}{|c|}{ Experience of social support } & \multirow{2}{*}{$\begin{array}{l}\mathbf{n}(\%) \\
138(43.4)\end{array}$} & \multicolumn{2}{|c|}{ Experience of social support } & \multirow{2}{*}{$\begin{array}{l}\text { n (\%) } \\
312(98.1)\end{array}$} \\
\hline With whom you & Spouse only & & What was the source of & HIV counselors & \\
\hline lived in the past & Family & $121(38.1)$ & information you used to & Peer discussion & $158(49.7)$ \\
\hline \multirow[t]{2}{*}{3 months? } & Living alone & $50(15.7)$ & cope up with HIVIAIDS? & $\mathrm{TV}$, radio, and & $135(42.5)$ \\
\hline & Friends & $9(2.8)$ & & news paper & \\
\hline Number of people & $\mathrm{I}-3$ & $142(53.0)$ & & programs & \\
\hline living with you in the & $4-5$ & $100(37.3)$ & & Home-based & $60(18.9)$ \\
\hline house & More than 6 & $26(9.7)$ & & care providers & \\
\hline Are you a member & No & $248(72.0)$ & & Other source & $5(1.6)$ \\
\hline of associations of & Yes & $70(22.0)$ & Have you got any support & Yes & $174(54.7)$ \\
\hline PLWHA and NEP+ & & & within the past 3 months? & No & I $44(45.3)$ \\
\hline Do you have & Yes & $315(99.1)$ & Who provided the & Relatives & $85(48.9)$ \\
\hline regular source of & No & $3(0.9)$ & support for you? $(\mathrm{N}=174)$ & NGO & $55(31.6)$ \\
\hline information to cope & & & & GO & $14(8.0)$ \\
\hline \multirow[t]{3}{*}{ with HIV? } & & & & Neighbors & II (6.3) \\
\hline & & & & Religious group & $9(5.2)$ \\
\hline & & & & and others & \\
\hline
\end{tabular}

Abbreviations: ART, antiretroviral treatment; PLWHA, people living with HIVIAIDS; NEP+, networks of positive people; NGO, nongovernmental organization; GO, governmental organization.

Table 4 Items, factor scores, and approval responses $(\mathrm{N}=3$ 18) of experienced HIV stigma among ART clients in Jimma town

\begin{tabular}{|c|c|c|c|}
\hline Experienced HIV stigma items & Factor score & Mean (SD) & $\begin{array}{l}\text { Approval } \\
\text { responses, } \\
\text { n (\%) }\end{array}$ \\
\hline I have been aware of being gossiped about & 0.79 & $3.4(1.3)$ & $186(58.5)$ \\
\hline I have been aware of being verbally insulted or harassed & 0.76 & $2.7(1.3)$ & 127 (39.9) \\
\hline My spouse/partner experienced discrimination & 0.54 & $2.6(1.0)$ & $97(30.5)$ \\
\hline I have been discriminated by other PLWHA & 0.78 & $2.2(1.1)$ & $71(22.3)$ \\
\hline I have been subjected to physical pressure or manipulation & 0.66 & $2.2(1.2)$ & $66(20.8)$ \\
\hline I have been excluded from social gatherings & 0.81 & $2.2(1.5)$ & $64(2 I .1)$ \\
\hline I have faced sexual rejection & 0.64 & $2.2(1.2)$ & $63(19.8)$ \\
\hline I have been excluded from family activities & 0.61 & $2.2(1.4)$ & $54(17.0)$ \\
\hline I have been forced to change place of residence & 0.71 & $2.1(0.9)$ & $54(17.0)$ \\
\hline Being physically harassed or threatened & 0.78 & $1.9(1.3)$ & $36(11.3)$ \\
\hline Being physically assaulted & 0.8 & $\mathrm{I} .8(\mathrm{I} .2)$ & $28(8.8)$ \\
\hline I have been excluded from religious activities & 0.87 & $1.8(1.5)$ & $28(8.8)$ \\
\hline I have lost my job or source of income & 0.66 & $1.8(0.9)$ & $24(7.5)$ \\
\hline I was forced to change job or was refused promotion & 0.54 & $1.7(0.8)$ & $20(6.3)$ \\
\hline Being refused employment/job opportunity & 0.59 & $1.7(0.8)$ & $20(6.3)$ \\
\hline Being dismissed, suspended, or prevented from education & 0.71 & $1.6(0.7)$ & $10(3.1)$ \\
\hline Being denied from family planning service & 0.88 & $\mathrm{I} .6(0.7)$ & $10(3.1)$ \\
\hline Being denied dental/health care services & 0.88 & $\mathrm{I} .5(0.7)$ & $9(2.8)$ \\
\hline
\end{tabular}

Abbreviations: ART, antiretroviral treatment; SD, standard deviation; PLWHA, people living with HIVIAIDS.

$p=0.00 ; 95 \%$ CI 9.6, 19.3). Those PLWHA who entered into ART program recently (1 year and less) had higher experienced HIV stigma score $(\beta=13.0 ; p=0.000 ; 95 \%$ CI 8.1, 17.9) compared to those who were undergoing ART for 6 years and above. Nevertheless, there was an inverse relationship between experienced stigma score and number of occupants in the house. Higher family size reduced the score of experienced HIV stigma on average by 3.97 compared to family with less than four family members $(\beta=-3.97 ; p=0.019 ; 95 \%$ CI -7.3, -1.7) (Table 7).

\section{Factors associated with internalized HIV stigma}

The stigma score was higher by 30.0 among uneducated respondents compared to respondents who attended at least secondary (Grade 9-12) education ( $\beta=30.0 ; p=0.00 ; 95 \%$ CI $22.3,37.7)$. Respondents who began ART program recently ( 1 year and less) had higher scores by 20.8 ( $\beta=20.8 ; p=0.000$; $95 \%$ CI 13.3, 28.4) compared to those who were on ART for 6 years and above. The internalized stigma score was 
Table 5 Items, factor scores, and approval responses $(\mathrm{N}=318)$ of internalized HIV stigma among ART clients in Jimma town

\begin{tabular}{|c|c|c|c|}
\hline Internalized stigma items & $\begin{array}{l}\text { Factor } \\
\text { score }\end{array}$ & $\begin{array}{l}\text { Mean } \\
\text { (SD) }\end{array}$ & $\begin{array}{l}\text { Approval } \\
\text { response, } \\
\text { n (\%) }\end{array}$ \\
\hline $\begin{array}{l}\text { My self-esteem lowered due to } \\
\text { HIV-positive status }\end{array}$ & 0.86 & $3.6(1.4)$ & $226(7 I .1)$ \\
\hline $\begin{array}{l}\text { I feel ashamed for being } \\
\text { HIV-positive }\end{array}$ & 0.84 & $3.6(1.4)$ & $221(69.5)$ \\
\hline $\begin{array}{l}\text { I am afraid of being gossiped } \\
\text { about }\end{array}$ & 0.50 & $3.4(1.6)$ & $199(62.9)$ \\
\hline $\begin{array}{l}\text { I blamed myself for being } \\
\text { HIV-positive }\end{array}$ & 0.63 & $3.0(1.6)$ & $153(48.1)$ \\
\hline I feel guilty for being HIV-positive & 0.78 & $3.0(1.4)$ & $144(45.3)$ \\
\hline $\begin{array}{l}\text { I blamed others for my } \\
\text { HIV-positive status }\end{array}$ & 0.36 & $2.8(1.6)$ & $126(39.6)$ \\
\hline $\begin{array}{l}\text { I decided not to have children } \\
\text { due to my HIV-positive status }\end{array}$ & 0.81 & $2.6(1.5)$ & $108(34.0)$ \\
\hline $\begin{array}{l}\text { Being afraid and verbally insulted } \\
\text { for being HIV-positive }\end{array}$ & 0.74 & $2.5(1.5)$ & $113(35.5)$ \\
\hline $\begin{array}{l}\text { I decided not to have sex due to } \\
\text { HIV-positive status }\end{array}$ & 0.88 & $2.4(1.4)$ & $86(27.0)$ \\
\hline $\begin{array}{l}\text { I decided not to get married due } \\
\text { to HIV-positive status }\end{array}$ & 0.85 & $2.3(1.4)$ & $76(23.9)$ \\
\hline $\begin{array}{l}\text { Being afraid that someone might } \\
\text { reject sexual relation }\end{array}$ & 0.70 & $2.2(1.3)$ & $63(19.8)$ \\
\hline $\begin{array}{l}\text { I had suicidal feeling for being } \\
\text { HIV-positive }\end{array}$ & 0.65 & $2.1(1.2)$ & $49(15.4)$ \\
\hline $\begin{array}{l}\text { I feel to be punished for being } \\
\text { HIV-positive }\end{array}$ & 0.82 & $2.0(1.1)$ & $44(13.8)$ \\
\hline $\begin{array}{l}\text { I am afraid of being physically } \\
\text { threatened or assaulted }\end{array}$ & 0.79 & $1.9(1.2)$ & $41(12.9)$ \\
\hline $\begin{array}{l}\text { I decided to stop working due to } \\
\text { HIV-positive status }\end{array}$ & 0.64 & $\mathrm{I} .8(\mathrm{I} .0)$ & $31(9.7)$ \\
\hline $\begin{array}{l}\text { I decided not to attend social } \\
\text { gatherings due to HIV-positive } \\
\text { status }\end{array}$ & 0.89 & $\mathrm{I} .8(0.9)$ & $28(8.8)$ \\
\hline $\begin{array}{l}\text { I decided to withdraw from } \\
\text { education/training }\end{array}$ & 0.72 & $1.8(1.0)$ & $25(7.9)$ \\
\hline
\end{tabular}

Abbreviations: ART, antiretroviral treatment; SD, standard deviation.

higher for respondents who were tested after they knew that their spouse died due to HIV ( $\beta=29.2 ; p=0.000 ; 95 \%$ CI $15.3,43.1)$ compared to those tested due to self-motivation (Table 8).

\section{Factors associated with perceived HIV stigma}

Multiple linear regression analysis indicated that PLWHA who entered into the ART program recently ( 1 year and less) had higher perceived HIV stigma score (33.2) $(\beta=33.2$; $p=0.00 ; 95 \%$ CI $22.9,43.4)$ compared to those who were on ART for 6 and more years. Provider-initiated testing (e.g. testing due to tuberculosis referral) had increased the
Table 6 Items, factor scores, and approval responses $(n=318)$ of perceived HIV stigma among ART clients in Jimma town

\begin{tabular}{|c|c|c|c|}
\hline $\begin{array}{l}\text { Perceived HIV stigma } \\
\text { items }\end{array}$ & $\begin{array}{l}\text { Factor } \\
\text { score }\end{array}$ & $\begin{array}{l}\text { Mean } \\
(\mathrm{SD})\end{array}$ & $\begin{array}{l}\text { Approval } \\
\text { response, } \\
\text { n (\%) }\end{array}$ \\
\hline $\begin{array}{l}\text { I am afraid about people } \\
\text { discriminating against me }\end{array}$ & 0.77 & $3.4(1.5)$ & $191(60.1)$ \\
\hline $\begin{array}{l}\text { I am worried that people may } \\
\text { tell my HIV status to others }\end{array}$ & 0.86 & $3.4(1.4)$ & I7I (53.8) \\
\hline $\begin{array}{l}\text { I told people close to me to } \\
\text { keep my HIV status as a secret }\end{array}$ & 0.77 & $3.3(1.5)$ & 165 (5I.9) \\
\hline $\begin{array}{l}\text { I think that people would be } \\
\text { afraid of me if they knew my } \\
\text { HIV status }\end{array}$ & 0.83 & $3.3(1.4)$ & 165 (5I.9) \\
\hline $\begin{array}{l}\text { I am working hard to keep } \\
\text { my HIV status as a secret }\end{array}$ & 0.85 & $3.2(1.6)$ & I 85 (58.2) \\
\hline $\begin{array}{l}\text { I feel that no one knows my } \\
\text { HIV-positive status }\end{array}$ & 0.71 & $2.8(1.5)$ & $122(38.4)$ \\
\hline $\begin{array}{l}\text { I feel guilty because of my } \\
\text { HIV-positive status }\end{array}$ & 0.70 & $2.5(1.4)$ & $86(27.0)$ \\
\hline $\begin{array}{l}\text { I feel I am a bad person due } \\
\text { to my HIV-positive status }\end{array}$ & 0.79 & $2.2(1.3)$ & $56(17.6)$ \\
\hline $\begin{array}{l}\text { People told me that HIV is } \\
\text { what I deserved }\end{array}$ & 0.76 & $2.2(1.3)$ & $59(18.6)$ \\
\hline $\begin{array}{l}\text { I feels I am unclean due to } \\
\text { my HIV-positive status }\end{array}$ & 0.73 & $2.0(I . I)$ & $49(15.4)$ \\
\hline
\end{tabular}

Abbreviations: ART, antiretroviral treatment; SD, standard deviation.

perceived HIV stigma score by 40 compared to those tested due to self-motivation $(\beta=40.1 ; p=0.00 ; 95 \%$ CI $37.6,50.7)$. On the contrary, perceived HIV stigma score had an inverse relationship with the respondents' status of membership to associations of PLWHA and NEP+; the score had reduced by 10.3 for the members of associations of PLWHA and NEP+ compared to those of nonmembers ( $\beta=-10.3 ; p=0.00 ; 95 \%$ CI -15.6, -4.9) (Table 9).

\section{Comparison across the stigma domains}

The magnitude of the three HIV stigma domains indicated that experienced HIV stigma was slightly lower than the rest of the stigmas including the overall HIV stigma. Internalized HIV stigma was higher than experienced HIV stigma, but lower than the perceived HIV stigma. Common predictors of the three HIV stigma domains were years of attending ART service, reason for HIV testing, and the power of decision during the first diagnosis. The educational status and occupation of the respondents were predictors of both internalized and experienced HIV stigmas in which being uneducated intensified the score of both HIV stigma domains. 
Table 7 Factors associated with experienced HIV stigma from multiple linear regression models

\begin{tabular}{|c|c|c|c|c|c|c|}
\hline \multirow[t]{2}{*}{ Characteristics } & & \multicolumn{2}{|c|}{$\begin{array}{l}\text { Unstandardized } \\
\text { coefficients }\end{array}$} & \multirow[t]{2}{*}{ Sig } & \multicolumn{2}{|c|}{$95 \% \mathrm{Cl}$ for $\beta$} \\
\hline & & $\boldsymbol{\beta}$ & SE & & Lower & Upper \\
\hline$\overline{S e x}$ & Female & 6.73 & 1.77 & 0.000 & 3.3 & 10.2 \\
\hline \multirow[t]{3}{*}{ Marital status } & Single (unmarried) & 9.41 & 2.92 & 0.001 & 3.7 & 15.1 \\
\hline & Widowed & 12.27 & 2.58 & 0.000 & 7.2 & 17.4 \\
\hline & Divorced (reference) & & & & & \\
\hline \multirow[t]{3}{*}{ Education } & No formal education & 14.47 & 2.45 & 0.000 & 9.6 & 19.3 \\
\hline & Elementary education & 10.83 & 2.05 & 0.000 & 6.8 & 14.9 \\
\hline & Secondary school (Grade 9-12) (reference) & & & & & \\
\hline \multirow[t]{3}{*}{ Occupation } & Fulltime private employee & 9.52 & 2.98 & 0.002 & 3.7 & 15.4 \\
\hline & Other & 9.38 & 3.63 & 0.010 & 2.2 & 16.5 \\
\hline & Daily laborer (reference) & & & & & \\
\hline \multirow[t]{3}{*}{ Number of family members } & 4-5 family members & -3.97 & 1.68 & 0.019 & -7.3 & 01.7 \\
\hline & More than 6 family members & -6.20 & 2.81 & 0.028 & -11.7 & -1.7 \\
\hline & I-3 family members (reference) & & & & & \\
\hline \multirow[t]{3}{*}{ Years of ART use } & Less than I & 13.00 & 2.47 & 0.000 & 8.1 & 17.9 \\
\hline & $2-3$ & 6.20 & 2.15 & 0.004 & 2.0 & 10.4 \\
\hline & 6 or more (reference) & & & & & \\
\hline \multirow{4}{*}{$\begin{array}{l}\text { Reason for HIV testing for } \\
\text { the first time }\end{array}$} & Testing for HIV due to spouse being & 10.10 & 3.32 & 0.003 & 3.6 & 16.6 \\
\hline & HIV-positive & & & & & \\
\hline & Testing for HIV due to referral for TB & 6.31 & 1.94 & 0.001 & 2.5 & 10.1 \\
\hline & Testing simply to know status (reference) & & & & & \\
\hline \multirow[t]{2}{*}{ Decision for the HIV testing } & Testing due to coercion & 11.88 & 4.20 & 0.005 & 3.613 & 20.1 \\
\hline & Voluntary testing (reference) & & & & & \\
\hline
\end{tabular}

Abbreviations: $\mathrm{Cl}$, confidence interval; SE, standard error; ART, antiretroviral treatment; TB, tuberculosis; sig, significance.

Table 8 Factors associated with internalized HIV stigma from multiple regression models

\begin{tabular}{|c|c|c|c|c|c|c|}
\hline \multirow[t]{2}{*}{ Characteristics } & & \multicolumn{2}{|c|}{$\begin{array}{l}\text { Unstandardized } \\
\text { coefficients }\end{array}$} & \multirow[t]{2}{*}{ Sig } & \multicolumn{2}{|c|}{$95 \% \mathrm{Cl}$ for $\beta$} \\
\hline & & $\boldsymbol{\beta}$ & SE & & Lower & Upper \\
\hline \multirow[t]{3}{*}{ Educational status } & No formal education & 30.03 & 3.91 & 0.000 & 22.3 & 37.7 \\
\hline & Elementary education & 25.69 & 3.12 & 0.000 & 19.5 & 31.8 \\
\hline & Secondary (Grade 9-12) school (reference) & & & & & \\
\hline \multirow[t]{2}{*}{ Occupation } & Other occupations & 17.63 & 6.11 & 0.004 & 5.6 & 29.7 \\
\hline & Daily laborer (reference) & & & & & \\
\hline \multirow[t]{2}{*}{ Years of ART use } & I or less & 20.81 & 3.83 & 0.000 & 13.3 & 28.4 \\
\hline & 6 or more (reference) & & & & & \\
\hline Reason for first HIV & Testing due to spouse being positive & 33.32 & 5.64 & 0.000 & 22.2 & 44.4 \\
\hline \multirow[t]{3}{*}{ testing } & Testing due to spouse death & 29.16 & 7.07 & 0.000 & 15.3 & 43.1 \\
\hline & Testing due to TB referral & 26.80 & 2.86 & 0.000 & 21.2 & 32.4 \\
\hline & Simply to know status (reference) & & & & & \\
\hline Decision to conduct & Testing by coercion & 19.13 & 5.23 & 0.000 & 8.8 & 29.4 \\
\hline the first HIV testing & VCT (voluntary testing) (reference) & & & & & \\
\hline Experience of social & More than 6 family members & -9.20 & 3.50 & 0.009 & -16.1 & -2.3 \\
\hline \multirow[t]{2}{*}{ support } & I-3 family members (reference) & & & & & \\
\hline & Being member of association of PLWHA, NEP+ & -7.00 & 2.24 & 0.002 & -11.4 & -2.6 \\
\hline
\end{tabular}

Abbreviations: $\mathrm{Cl}$, confidence interval; SE, standard error; ART, antiretroviral treatment; TB, tuberculosis; VCT, HIV counseling and testing; PLWHA, people living with HIVIAIDS; NEP+, network of positive people.

\section{Discussion}

More than 30 years passed after HIV epidemic emerged; various prevention and control measures have been taken across the world to overcome the social, health, and economic effects of the pandemic. However, HIV-related stigma remains highly prevalent in most parts of the world. Therefore, different researches are needed to provide a greater understanding of the problem in HIV-infected individuals and the society in general including contextualized prevention strategies. PLWHA can develop negative beliefs about 
Table 9 Factors associated with perceived HIV stigma from multiple linear regression models

\begin{tabular}{|c|c|c|c|c|c|c|}
\hline \multirow[t]{2}{*}{ Characteristics } & & \multicolumn{2}{|c|}{$\begin{array}{l}\text { Unstandardized } \\
\text { coefficients }\end{array}$} & \multirow[t]{2}{*}{ Sig } & \multicolumn{2}{|c|}{$95 \% \mathrm{Cl}$ for $\beta$} \\
\hline & & $\beta$ & SE & & Lower & Upper \\
\hline \multirow[t]{2}{*}{ Years of taking ART drug } & I or less & 33.2 & 5.22 & 0.000 & 22.9 & 43.4 \\
\hline & 6 or more (reference) & & & & & \\
\hline \multirow[t]{2}{*}{ Reason for the first HIV testing } & Testing due to TB referral & 44.1 & 3.31 & 0.000 & 37.6 & 50.7 \\
\hline & Simply to know status (reference) & & & & & \\
\hline Decision to conduct the first HIV & Testing by coercion & 18.1 & 6.31 & 0.004 & 5.7 & 30.5 \\
\hline testing & VCT (voluntary testing) (reference) & & & & & \\
\hline \multirow[t]{2}{*}{ Involuntary disclosure by others } & Status revealed by family members & 22.0 & 7.27 & 0.003 & 7.70 & 36.3 \\
\hline & $\begin{array}{l}\text { Status revealed by spouse/sexual partners } \\
\text { (reference) }\end{array}$ & & & & & \\
\hline Being member of NEP+ and & Members of association of PLWHA, NEP+ & -10.3 & 2.70 & 0.000 & -15.6 & -4.9 \\
\hline association & Nonmembers of association of PLWHA (reference) & & & & & \\
\hline \multirow[t]{2}{*}{ Social support providers } & NGO & 23.6 & 5.30 & 0.000 & 13.1 & 33.9 \\
\hline & Religious groups (reference) & & & & & \\
\hline
\end{tabular}

Abbreviations: $\mathrm{Cl}$, confidence interval; SE, standard error; ART, antiretroviral treatment; TB, tuberculosis; VCT, HIV counseling and testing; NEP+, network of positive people; PLWHA, people living with HIVIAIDS; NGO, nongovernmental organization; sig, significance.

HIV and stigmatize themselves, which is referred to as self-stigma or internalized stigma. They can also develop fear of being stigmatized by the public which is referred to as perceived stigma. Both forms of HIV stigmas will be intensified by enacted/experienced stigma through acts of discrimination, abuse, or ostracism. Thus, this facility-based cross-sectional study was conducted to measure the level of the three forms of HIV stigmas and to assess the factors affecting the level of stigmas among PLWHA in ART clinics in Jimma town.

In this study, the female living with HIV/AIDS had a consistently higher mean score of the three forms of stigmas than the males, but sex was statistically significantly associated only with experienced HIV stigma. This finding was consistent with the study conducted in Kenya, which indicated that many women living with HIV reported high levels of stigma, resulting in a desire to hide their status from family and friends for fear of being discriminated against. ${ }^{22}$ The reason for the high HIV stigma score could be that HIV-related stigma builds upon other existing gender-related prejudices. Women may suffer more stigmas because the community views them as having been promiscuous at least once in their lifetime when they are infected with HIV. However, most evidences suggest that women acquired the virus from their male sex partners and biologically infected through unprotected heterosexual intercourse than men. ${ }^{23}$

The mean score of experienced HIV stigma was lower than the rest of stigma domains, which may be due to the fact that the majority of the clients were from the urban setting providing relatively better access to various media that develop the positive attitude toward PLWHA among public. The magnitude of experienced HIV stigma was slightly lower than finding of the study conducted in Malawi (43.0\%) and Kenya (22.8\%). ${ }^{24}$ Out of the 18 experiences of discrimination, gossip, verbal insult, psychological pressure or manipulation, and harassment were the most prevalent (58.5\%, 39.9\%, 20.8\%, and $11.3 \%$, respectively). These scores were slightly higher than those found in a study conducted in Cambodia (gossip: 37.6\%, manipulation and psychological pressure: $33.9 \%$, harassment and threats: $24.6 \%) .{ }^{25}$ The variations may be due to the difference in the study period and study setting.

The experience of denial of health service was scored the lowest among the experienced HIV stigma items, which was about $2.9 \%$ for denial of dental care and almost the same for denial of family planning services. This result could be an indication of positive attitude toward PLWHA from the service providers, but still needs attention since $3.5 \%$ of the respondents blamed service providers for involuntary sero-status disclosure and 3.5\% for coercive HIV testing. Moreover, the exclusion of PLWHA from different public gatherings is not eliminated. The current survey indicated that $17.0 \%$ of respondents excluded from social gatherings, $7.5 \%$ from religious activities, and $19.8 \%$ from family activities at least once in the past 12 months, which was in line with stigma index validation survey conducted in seven Asia Pacific countries. ${ }^{26}$

Moreover, the act of discrimination toward PLWHA was not only from the public but also from PLWHA themselves; 
$22.3 \%$ of study participants indicated that they were discriminated by other PLWHA at least once in the past 12 months. This may be due to lower awareness about the HIV transmission and the weakness of the associations of PLWHA and NEP+ to bring the victims together, discuss on their commonalities, and stand together for their rights rather than discriminating one another. The survey indicated that being member of associations of PLWHA has a statistically significant association with HIV stigma. The prevalence of HIV stigma among the members of association of PLWHA is much lower $(3.5 \%)$ as compared to nonmembers of the association (12.3\%). This may be because associations of PLWHA and NEP+ provide appropriate coping mechanisms to improve the self-esteem of their members.

Our result illustrated that being single in marital status and educational levels (uneducated and elementary education) were significantly associated with experienced HIV stigma. It showed that lower level of education had a positive association with the experienced HIV stigma. This finding is against the study conducted in Canada which indicated that among participants with high school education or greater, the outcome stigma was decreasing. ${ }^{27}$ Number of years of ART utilization was another factor significantly associated to all HIV stigma domains. Those who newly entered into ART program had high stigma score as compared to those using ART for long period. Therefore, at this time, health care providers should exert significant assistance to build self-esteem of the ART newcomers to resist internal and external challenges.

In this survey, $69.5 \%$ of PLWHA felt ashamed, more than half $(62.6 \%)$ had fear of being gossiped about, $45.3 \%$ felt guilt, and $48.1 \%$ blamed themselves for being HIV-positive. This finding was closer to the study conducted in Sri Lanka to validate HIV stigma index in which 54\% of the PLWHA felt ashamed, $45.5 \%$ felt guilty, and $51 \%$ blamed self for being HIV-positive. ${ }^{28}$ The major difference is that in the case of Sri Lanka, male PLWHA were more stigmatized than females, but in the current study, female living with HIV/AIDS were more stigmatized than males. This may be due to differences in the sociocultural and economic status of both countries. In the current setting, there is a culture of male domination that may be linked with HIV-related stigma as well.

Social support is another factor that affects the level of internalized HIV stigma in this study. The score among those who received social support $(21.1 \%)$ was significantly less than that of unsupported $(30.2 \%)$ respondents. However, there is an indication that the social care and support provision should be based on appropriate social and ethical procedures. Out of the participants who received social support at least once from a close family member within the past 3 months, $19.5 \%$ had high internalized HIV stigma score compared to $11.5 \%$ of those supported by nongovernmental organizations (NGOs). This may be due to variation in skill of providing support services between an ordinary family member and trained professional support providers from NGOs. On the contrary, those PLWHA supported by NGOs (5.2\%) had high experienced HIV stigma score as compared to those supported by family members $(3.4 \%)$. This may be due to support provided by NGOs to the total community and exposed the support receiver to be viewed as a unique person from the rest of the community.

\section{Conclusion}

This study revealed that PLWHA in Jimma town had a relatively lower level of experienced HIV stigma but high level of internalized and perceived HIV stigma. Years of ART use, reason for the first HIV test, and decision power for the first HIV testing were those statistically significant factors across the three HIV stigma domains. Out of the different stigmatizing experiences, gossip and verbal insult caused a high level of self-exclusion from different societal gatherings. The perceived HIV stigma score was the higher compared with different countries.

\section{Recommendation}

Stigma reduction interventions collaborating community leaders, health care personnel, and networks of PLWHA need to be designed to decrease the HIV stigma. The intervention should focus on ecological models to reduce the high level of perceived and internalized HIV stigma. The ART nurses should provide HIV counseling services according to the client's years of ART utilization. Associations of PLWHA and NEP+ in the town should work together to address the entire PLWHA in the town and establish a strong counseling service that focuses on individual level than group attention.

\section{Authors' contribution}

NNF conducted the study from formulating the design to data collection, data analysis, and the manuscript preparation. ZB and MA contributed in approval of proposal development, data analysis, and manuscript preparation. All authors contributed toward data analysis, drafting and critically revising the paper and agree to be accountable for all aspects of the work. 


\section{Acknowledgments}

The authors would like to acknowledge the participants of this study for their willingness and innocence and the data collectors' dedication. They would also like to express their gratitude to Jimma University College of Public Health and Medical Sciences, particularly the Department of Health Education and Behavioral Sciences, for providing them this excellent opportunity and unreserved support to complete the study. Finally, they would like to acknowledge the health facilities for their cooperation during the study period.

\section{Disclosure}

The authors report no conflicts of interest in this work.

\section{References}

1. UNAIDS. Global summary of the AIDS epidemic. AIDS epidemic update. 2013.

2. Central Statistical Agency. Ethiopia Demographic and Health Survey; 2011. Available from: http://www.stigmaindex.org/sites/default/ files/reports/EthiopianPLHIV\%20Stigma\%20Index\%20Country\%20 Report\%202011.pdf. Accessed May 20, 2015.

3. Federal Democratic Republic of Ethiopia. Country Progress Report on HIV/AIDS Response, 2012. Available from: http://s3.amazonaws. com/zanran_storage/www.unaids.org/ContentPages/2546109285.pdf. Accessed

4. Federal Democratic Republic of Ethiopia. Single Point HIV Prevalence Estimate. Available from: http://www.etharc.org/aidsineth/publications/ singlepointprev_2007.pdf. Accessed

5. Horizons/Population Council. HIV/AIDS-related stigma and discrimination: a conceptual framework and an agenda for action. ICRW. Available from: http://apps.who.int/iris/bitstream/10665/61546/1/ WHO_SPA_INF_87.12.pdf. Accessed May 21, 2015.

6. Mann JM. Statement at an informal briefing on AIDS. Presented at the 42nd Session of the United Nations General Assembly; October 20, 1987.

7. Orner P. Psychosocial impacts on caregivers of people living with AIDS. AIDS Care. 2006;18(3):236-240.

8. Lutz B. Can (Conditional) Cash Transfers Contribute to HIV Prevention for Girls? Geneva: UNESCO, Gender Equality, HIV and Education; 2012. Available from: http://www.lgbt education.info/doc/unesco/ UNESCO_GPP_Gender_Equality_HIV_and_Education_2012.pdf. Accessed May 21, 2015.

9. UNAIDS. Reducing HIV Stigma and Discrimination: A Critical Part of National AIDS Program. Geneva: Joint United Nations Program on HIV/AIDS; 2007. Available from: http://www.unaids.org/sites/default/ files/media_asset/jc1521_stigmatisation_en_1.pdf. Accessed June 10, 2015.

10. Visser MJ, Kershaw T, Makin JD, Forsyth BW. Development of parallel scales to measure HIV-related stigma. AIDS Behav. 2008;12(5): 759-771.

11. Office of National AIDS Policy. National HIV/AIDS strategy for the United States. 2010. Available from: http://www.whitehouse.gov/sites/ default/files/uploads/NHAS.pdf.
12. Sayles JN, Wong MD, Kinsler JJ, Martins D, Cunnigham WE. The association of stigma with self-reported access to medical care and antiretroviral therapy adherence in persons living with HIV/AIDS. J Gen Intern Med. 2009;24(10):1101-1108.

13. Li L, Lin C, Wu Z, Rotheram-Borus MJ, Detels R, Jia M. Stigmatization and shame: consequences of caring for HIV/AIDS patients in China. AIDS Care. 2007;19(2):258-263.

14. Rahmati-Najarkolaei, Niknami S, Aminshokravi F, et al. Experiences of stigma in healthcare settings among adults living with HIV in the Islamic Republic of Iran. J Int AIDS Soc. 2010;13:27.

15. Nattabi B, Li J, Thompson SC, Orach CG, Earnest J. Factors associated with perceived stigma among people living with HIV/AIDS in postconflict northern Uganda. AIDS Educ Prev. 2011;23(3):193-205.

16. Muoghalu CO, Jegede SA. The role of cultural practices and the family in the care for people living with HIV/AIDS among the Igbo of Anambra State, Nigeria. Soc Work Health Care. 2010;49(10):981-1006.

17. Okoror TA, Falade CO, Olorunlana A, Walker EM, Okareh OT. Exploring the cultural context of HIV stigma on antiretroviral therapy adherence among people living with HIV/AIDS in southwest Nigeria. AIDS Patient Care STDS. 2013;27(1):55-64.

18. Rensen C, Bandyopadhyay S, Gopal PK, Van Brakel WH. Measuring leprosy-related stigma - a pilot study to validate a toolkit of instruments. Disabil Rehabil. 2011;33(9):711-719.

19. UNAIDS. The global AIDS program (GAP) report. Beginning of the end of AIDS epidemic. 2014. Available from: http://www. unaids.org/ en/media/unaids/contentassets/documents/unaidspublication/2014/ UNAIDS_Gap_report_en.pdf. Accessed May 20, 2015.

20. NEP+. The People Living with HIV Stigma Index. Addis Ababa: NEP+; 2012. Available from: http://www.stigmaindex.org/sites/default/files/ reports/EthiopianPLHIV\%20Stigma\%20Index \%20Country\%20 Report\%202011.pdf. Accessed May 20, 2015.

21. SeyedAlinaghi S, Paydary K, Kazerooni PA, et al. Evaluation of stigma index among people living with HIV/AIDS (PLWHA) in six cities in Iran. Thrita. 2013;2(4):69-75.

22. Colombini M, Mutemwa R, Kivunaga J, Stackpool Moore L, Mayhew SH; Integra Initiative. Experiences of stigma among women living with HIV attending sexual and reproductive health services in Kenya: a qualitative study. BMC Health Serv Res. 2014;14:412.

23. AVERT. Women and HIV/AIDS. 2015. Available from: http://www. avert.org/women-and-hiv-aids.htm. Accessed June 1, 2015.

24. Neuman M, Obermeyer CM; MATCH Study Group. Experiences of stigma, discrimination, care and support among people living with HIV: a four country study. AIDS Behav. 2013;17(5):1796-1808.

25. CPN+. People Living with HIV Stigma Index Cambodia, 2010. Geneva: UNAIDS; 2010. Available from: http://www.stigmaindex.org/sites/ default/files/reports/Cambodia\%20People\%20Living\%20with\%20 HIV\%20Stigma\%20Index\%20Report\%202010.pdf. Accessed June 10, 2015.

26. UNAIDS. People Living with HIV Stigma Index. Asia Pacific Regional Analysis. Geneva: Switzerland; 2011. Available from: www.unaids.org. Accessed June 10, 2015.

27. Tzemis D, Forrest JI, Puskas CM, et al. Identifying self-perceived HIVrelated stigma in a population accessing antiretroviral therapy. AIDS Care. 2013;25(1):95-102.

28. UNAIDS; Family Planning Association Sri Lanka and Partners. People living with HIV stigma index in Sri Lanka. 2010. Available from: http:// www.unaids.org/sites/default/files/media_asset/jc1521_stigmatisation_en_1.pdf; http://www.stigmaindex.org/sites/default/files/reports/ Sri\%20Lanka\%20People\%20Living\%20with\%20HIV\%20Stigma $\% 20$ Index\%20Report\%20November-2010.pdf. Accessed June 12, 2015. 
HIV/AIDS - Research and Palliative Care

\section{Publish your work in this journal}

HIV/AIDS - Research and Palliative Care is an international, peerreviewed open access journal focusing on advances in research in HIV its clinical progression and management options including antiviral treatment, palliative care and public healthcare policies to control viral spread. The journal is included in PubMed. The manuscript man-

\section{Dovepress}

agement system is completely online and includes a very quick and fair peer-review system, which is all easy to use. Visit http://www.dovepress. com/testimonials.php to read real quotes from published authors.

Submit your manuscript here: https://www.dovepress.com/hivaids---research-and-palliative-care-journal 